\title{
Systematic review of vestibular disorders related to human immunodeficiency virus and acquired immunodeficiency syndrome
}

\author{
B HEINZE ${ }^{1}$, D W SWANEPOEL ${ }^{1,2}$, L M HOFMEYR $^{3}$ \\ ${ }^{1}$ Department of Communication Pathology, University of Pretoria, Pretoria, South Africa, ${ }^{2}$ Callier Center for \\ Communication Disorders, University of Texas at Dallas, USA, and ${ }^{3}$ Department of Otorhinolaryngology, \\ University of Pretoria, Pretoria, South Africa
}

\begin{abstract}
Introduction: Disorders of the auditory and vestibular system are often associated with human immunodeficiency virus infection and acquired immunodeficiency syndrome. However, the extent and nature of these vestibular manifestations are unclear.

Objective: To systematically review the current peer-reviewed literature on vestibular manifestations and pathology related to human immunodeficiency virus and acquired immunodeficiency syndrome.

Method: Systematic review of peer-reviewed articles related to vestibular findings in individuals with human immunodeficiency virus infection and acquired immunodeficiency syndrome. Several electronic databases were searched.

Results: We identified 442 records, reduced to 210 after excluding duplicates and reviews. These were reviewed for relevance to the scope of the study.

Discussion: We identified only 13 reports investigating vestibular functioning and pathology in individuals affected by human immunodeficiency virus and acquired immunodeficiency syndrome. This condition can affect both the peripheral and central vestibular system, irrespective of age and viral disease stage. Peripheral vestibular involvement may affect up to 50 per cent of patients, and central vestibular involvement may be even more prevalent. Post-mortem studies suggest direct involvement of the entire vestibular system, while opportunistic infections such as oto- and neurosyphilis and encephalitis cause secondary vestibular dysfunction resulting in vertigo, dizziness and imbalance.

Conclusion: Patients with human immunodeficiency virus and acquired immunodeficiency syndrome should routinely be monitored for vestibular involvement, to minimise functional limitations of quality of life.
\end{abstract}

Key words: HIV; Acquired Immunodeficiency Syndrome; Vestibular Function Tests; Dizziness; Vertigo; AIDSRelated Opportunistic Infections

\section{Introduction}

The global pandemic of human immunodeficiency virus and acquired immunodeficiency syndrome (HIV/AIDS) affects millions of people directly, and countless more indirectly. It is a multifaceted condition resulting in widespread clinical manifestations, including those in the head and neck area. ${ }^{1}$ Head and neck disease is amongst the most commonly reported manifestation of HIV/AIDS, and has been documented since the discovery of HIV in the early $1980 \mathrm{~s}^{2,3}$ The incidence of head and neck related symptoms of HIV / AIDS has been reported to vary between 40 and 90 per cent. ${ }^{4-7}$ Many of these symptoms are characterised by involvement of the auditory system, as a result of the direct effect of HIV infection, or indirectly due to a combination of opportunistic infections or associated ototoxic treatments. ${ }^{8,9}$

Auditory pathology associated with HIV/AIDS involves structures including the outer and middle ear, cochlea, neural pathways, and central nervous system (CNS). The disease may involve one or many of these structures. Opportunistic infections related to the outer and middle ear may include acute otitis externa ${ }^{10}$ and otitis media with effusion. ${ }^{11}$ Highly active antiretroviral therapy combinations may be ototoxic, as may some treatments for opportunistic infections, resulting in hearing loss, tinnitus and hyperacusis. ${ }^{12-14} \mathrm{~A}$ direct effect of HIV on the neural pathways, resulting in neural auditory disorders, has also been reported..$^{12,15,16}$ 
Although the exact incidence and prevalence of auditory disorders are unknown, as many as 75 per cent of adults with HIV/AIDS may present with auditory pathologies with aetiologies associated with $\mathrm{HIV} /$ AIDS. ${ }^{17}$

In addition to the auditory manifestations of HIV/ AIDS, vestibular dysfunction has also been documented. ${ }^{18}$ The cochlea and vestibular organ, situated in the temporal bone, are interconnected and constitute the membranous labyrinth; they also share the same fluids, namely endolymph and perilymph. Their nerve fibres together constitute the VIIIth cranial (cochleovestibular) nerve. ${ }^{19}$ Considering this shared anatomy and physiology, and the known effects of HIV/AIDS on the auditory system, it is not surprising that vestibular symptoms occur.

Individuals with vestibular involvement may present with symptoms such as vertigo or a sensation of spinning, ${ }^{20}$ and in some cases there may be subclinical vestibular damage. Despite being a common symptom of vestibular involvement, only a limited number of reports have investigated the prevalence of vertigo in patients with HIV/AIDS. One study ${ }^{21}$ reported that 9 per cent of individuals with HIV/AIDS complained of vertigo, while another reported the same complaint in 30 per cent of HIV/AIDS-affected adults. ${ }^{22,23}$ Such symptoms have probably been under-reported in individuals with HIV/AIDS due to the emphasis on the life-threatening aspects of the disease, as opposed to more chronic non-communicable disease processes.

The advent of highly active antiretroviral therapy and improvements in treatment accessibility are changing the face of AIDS, from an acute, life-threatening disease to a chronic condition. Thus, there is now a greater emphasis on quality of life concerns, as life expectancy increases for those living with the disease. ${ }^{24}$ Although a cure for HIV/AIDS may not yet exist, enhanced management of HIV-related diseases and symptoms could facilitate improved wellbeing.

Just as hearing loss affects communication and human interaction, other sensory deficits, such as vestibular disorders, may also negatively affect quality of life. ${ }^{25}$ Living with vestibular symptoms, such as vertigo or dizziness, may potentially restrict patients' activities of daily living, since such symptoms are often accompanied by anxiety, stress and fear of falling. In fact, the general health status of such patients is significantly affected by a perceived reduction in physical and socio-emotional functioning, associated with vertigo and dizziness. ${ }^{26}$ However, to date there has been little consensus on the extent and nature of the vestibular manifestations of HIV / AIDS.

The present study aimed to systematically review the current body of peer-reviewed publications on reported HIV/AIDS-related vestibular manifestations and pathology.

\section{Materials and methods}

A varied search strategy was employed, searching several electronic databases, to identify relevant research articles and conference proceedings (excluding reviews, editorials, notes, letters and short surveys) from the peer-reviewed literature. To merit inclusion, relevant articles had to relate to vestibular findings in patients with HIV/AIDS, and to the possible pathology of these findings.

Articles relating to vestibulotoxicity aetiology were excluded from this systematic review, since the vestibulotoxic effects of aminoglycosides (commonly used to treat HIV-related opportunistic infections) and other potentially ototoxic medications have been reviewed elsewhere. ${ }^{23,27,28}$ Many drugs may have vertigo and/ or dizziness as side effects, thus complicating the diagnosis of vestibulotoxicity.

All relevant articles and conference proceedings published before 1 February 2010 were included. Table I indicates the databases and search strategies employed.

The Medline database was searched using two strategies: (1) searching for HIV-related articles reporting vertigo in patients, and (2) searching for HIV-related articles reporting any vestibular finding in patients.

The second database search was conducted on Scopus. The search strategy aimed to identify HIVrelated articles reporting vestibular findings or vertigo in patients.

The third database search was conducted on PubMed, utilising Medical Subject Heading (MeSH) terms to locate articles reporting vestibular diseases with HIV, as well as vestibular function tests with HIV.

The search term 'dizziness' was omitted in all the database searches, since it is considered an imprecise $\mathrm{MeSH}$ term used to describe various sensations and symptoms each with a different pathophysiological mechanism and significance. In contrast, the terms 'vestibular' and 'vertigo' are strongly associated with involvement of the inner ear, vestibular nerve, brainstem and cerebral cortex; furthermore, the MeSH term 'vestibular diseases' includes the term vertigo, while the MeSH term 'vestibular function tests' includes caloric tests and electronystagmography. Thus, these terms were used in database searches.

By using a multifaceted approach, covering several databases and employing different search strategies, we aimed to ensure comprehensive coverage and to enable cross-checking of results.

All available English language abstracts were reviewed. Where abstracts were not available, the full paper was reviewed, and excluded if not directly relevant to our study objectives. After all duplicates and unrelated papers had been excluded, the remaining articles were reviewed according to the HIV/AIDSassociated vestibular findings reported. 


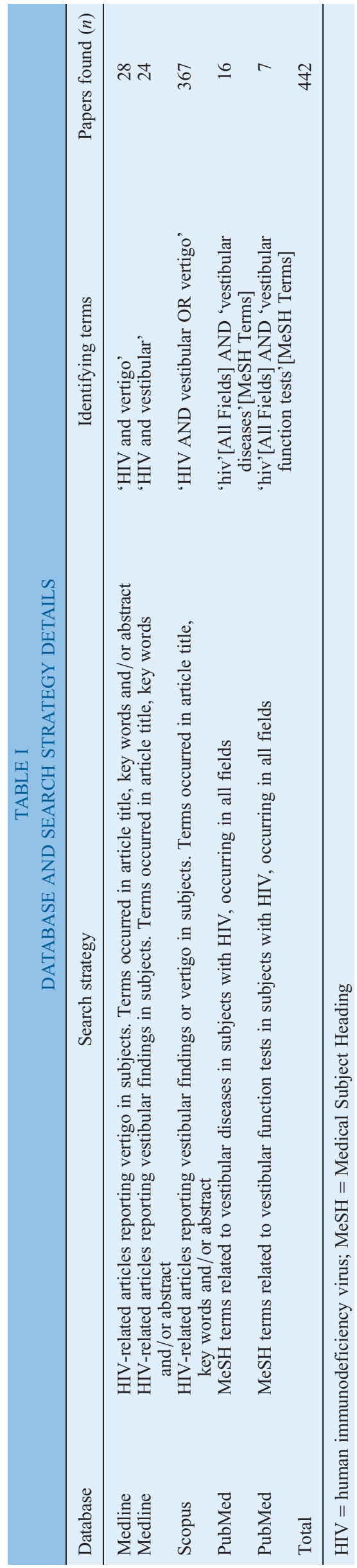

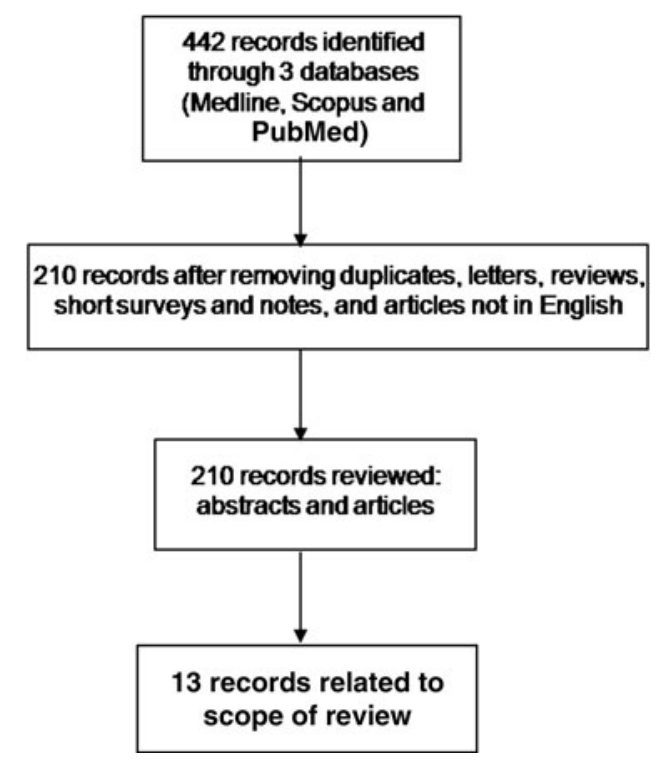

FIG. 1

Review procedure used to identify records for inclusion.

\section{Results and analysis}

Figure 1 summarises the different phases of our systematic review procedure used to identify reports for inclusion.

A total of 442 records were identified from the three databases. After excluding duplicates, letters, reviews, short surveys, notes and four non-English language articles, only 210 records remained. These remaining articles were reviewed by reading their abstracts, to determine their relevance to our study.

A total of 197 records were not directly relevant to the scope of our review, being unrelated to vestibular findings in individuals infected by HIV. The majority of excluded reports considered pharmacological side effects; others reported HIV-negative patients.

Only 13 articles reported vestibular functioning and pathology in individuals infected with HIV. Appendix I provides a brief summary of these articles.

Of these 13 articles, four were case presentations reporting the results of auditory and vestibular examination of adults presenting with vestibular symptoms. ${ }^{30,33,37,40}$

Seven group studies were identified, of which two were descriptive ${ }^{29,31}$ and five were quasi-experimental in nature. ${ }^{18,32,34,35,39}$ These group studies aimed to investigate the nature of vestibular disorders and types of vestibular manifestations associated with HIV/AIDS. All patients were adults, except for one study investigating HIV/AIDS-related vestibular function in children aged 16 years and below. ${ }^{29}$

Figure 2 illustrates the various vestibular tests described in the seven group studies. The most common test used was the smooth pursuit tracking test (a test for central vestibular functioning), followed by caloric irrigation (a peripheral vestibular test). Saccade testing (assessing central vestibular function) was used in four studies, along with positional or 


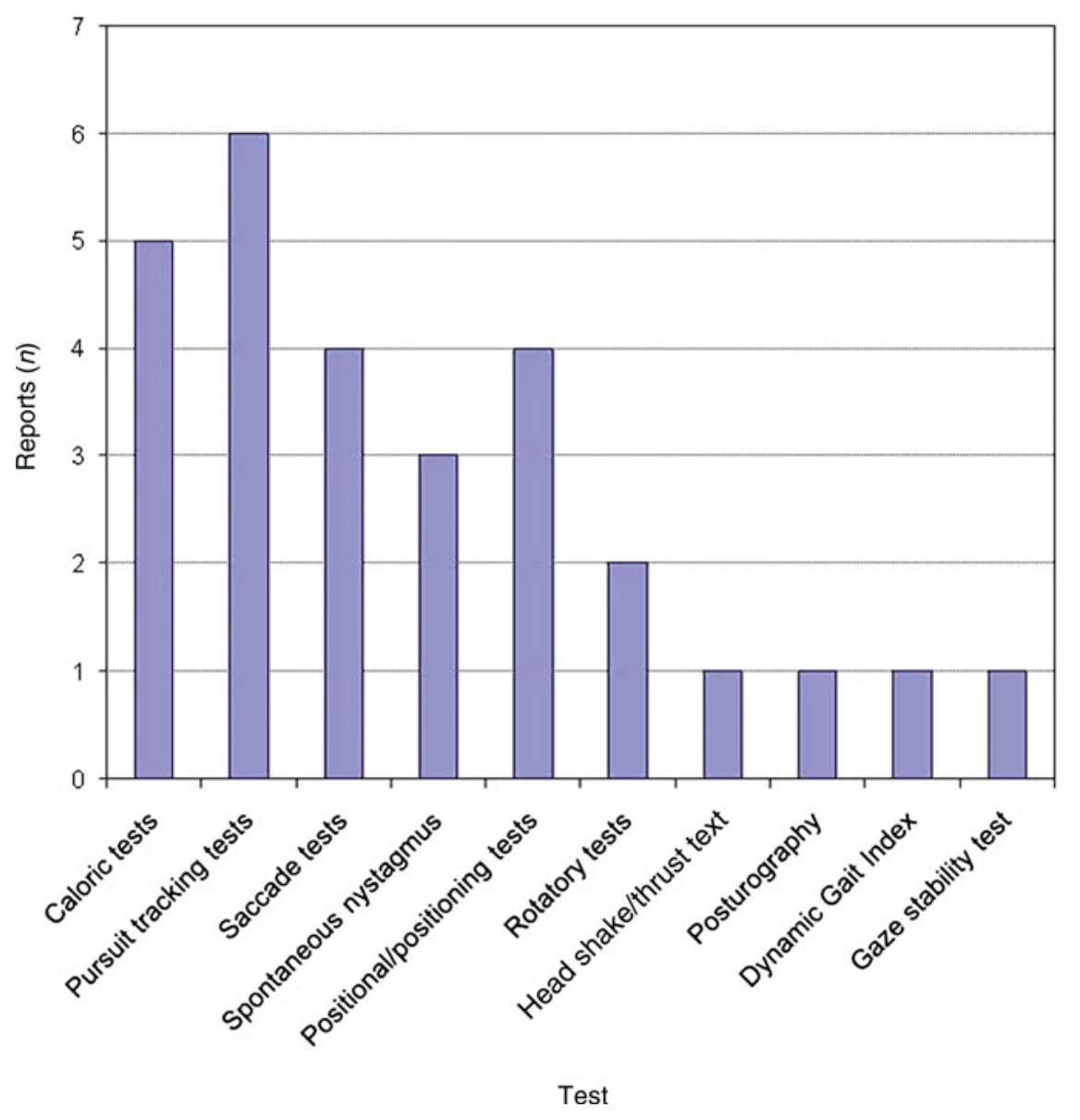

FIG. 2

Vestibular tests used in the reports retrieved.

positioning nystagmus tests. Three studies used spontaneous nystagmus testing, and two used rotatory tests. A single study utilised posturography, Dynamic Gait Index, head shake and thrust, and gaze stability testing.

Post-mortem studies accounted for three of the 13 articles. Two of these used electron microscopy to investigate the mechanism of vestibular pathology in the vestibular end-organs of 10 and 12 autopsy cases, variously, in confirmed patients with AIDS. ${ }^{36,38}$ The third report was a single case presentation which also included a post-mortem study of a patient with HIV. ${ }^{40}$

\section{Discussion}

\section{Vestibular system involvement in acquired immunodeficiency syndrome}

There are many more reports of the auditory manifestations of HIV/AIDS than the vestibular manifestations. The present review only identified seven reports of vestibular assessment in a group of HIV/ AIDS patients. Although it has been reported that vestibular disorders occur in 15 per cent of individuals infected with HIV, ${ }^{41}$ we could find only four reports identifying the prevalence of various types of vestibular involvement in infected adults.

Two reports ${ }^{34,39}$ employed a quasi-experimental research design comparing their patients' results with those of a control group of HIV-negative adults. Both these studies categorised their HIV-positive participants using the Centers for Disease Control criteria, as either stage II, III or IV. Participants in both studies were asymptomatic, with no neurological or vestibular symptoms, apart from a subgroup of 14 participants in Hausler and colleagues' study. ${ }^{39}$ These latter patients were however classified as stage IV and suffered from AIDS, opportunistic infections and AIDS-related complex.

Both these studies found that the CNS was involved even in the early stages of the disease. Results indicated poor oculomotor test performance and poor visual suppression, suggesting abnormalities in central vestibular functioning. These test results were evident at all disease stages, even in asymptomatic individuals with no reported neurological or vestibular symptoms. Castello et al. ${ }^{34}$ reported a 52 per cent prevalence of such central vestibular involvement in asymptomatic HIV-positive adults. Such involvement implicated the pons-cerebellar pathways, supratentorial areas, and pretectal and paramedian pontine regions, as 
demonstrated by abnormalities in the saccade and pursuit tracking tests. The cerebellar-vestibular pathways were affected in 82 per cent of asymptomatic HIV-positive adults, as indicated by nystagmic alterations observed during caloric tests. This CNS involvement occurred regardless of disease stage. Although caloric test results were quantitatively within normal limits and suggested normal labyrinth functioning, the lack of more comprehensive testing meant that peripheral vestibular involvement could not be excluded. Although Castello et $a l^{34}$ classified their patients according to the Centers for Disease Control criteria, the vestibular findings for each stage were not compared or discussed.

Three studies ${ }^{18,31,39}$ aimed to compare the prevalence of vestibular involvement at various stages of HIV infection (see Table II). One of these studies ${ }^{39}$ reported abnormal central vestibular functioning as the presenting feature in 22 per cent of asymptomatic stage II patients, 50 per cent of stage III patients and 57 per cent of stage IV patients (all stage IV patients complained of vestibular symptoms). Although only two patients (14 per cent) from the latter group had both abnormal peripheral and central vestibular functioning, it was not clear from the report what criteria had been used to distinguish abnormal peripheral versus central vestibular functioning. Teggi et al. ${ }^{31}$ reported a high prevalence of peripheral and central vestibular involvement. Results indicated that, among symptomatic HIV-positive adults in the advanced stages of HIV / AIDS, up to 40 per cent had both abnormal peripheral and central vestibular findings. However, these findings may have been influenced by the fact that, although all procedures were essentially identical to other, similar studies, Teggi and colleagues' test battery included the Dynamic Gait Index (a sensitive tool used to identify vestibular disorders and to assess risk of falling). Also of note, Hausler et al. ${ }^{39}$ defined abnormal caloric irrigation as a unilateral weakness of 40 per cent or more, although other authors have recommended setting normal limits for gain symmetry from as low as 22 per cent $^{41}$ to as high as 30 per cent. ${ }^{43}$ Teggi et al. $^{31}$ considered a difference of more than 15 per cent to indicate a labyrinthine preponderance. Given this variance in recommended normal limits, the incidence of peripheral vestibular involvement reported by Hausler et al. ${ }^{39}$ may have been greater if more conservative limits of normality had been employed.

Castello et al. ${ }^{34}$ utilised bithermal caloric irrigation, but quantitative caloric response parameters were within normal limits for the peripheral vestibular system (i.e. the labyrinth and the vestibular nerve pathway). Thus, these authors identified the CNS as the causal area affected. Both Hausler et al. ${ }^{39}$ and Castello et al. ${ }^{34}$ concluded that neurological complications are likely to occur in HIV-infected individuals, which may result in vestibular manifestations. Abnormalities in the oculomotor test results (i.e. saccade and smooth pursuit tracking) of HIV-positive adults with cluster of differentiation $4+$ glycoprotein cell counts below 500 cells $/ \mathrm{mm}^{3}$ also indicated neurological insults. ${ }^{35}$ Results for static and dynamic posturography $^{32}$ indicate that the CNS and vestibular system are involved at all stages of HIV/AIDS, including in asymptomatic individuals. This implies that balance problems, postural instability and/or disequilibrium may be found in all individuals with HIV/AIDS irrespective of disease stage. Thus, patients' quality of life and daily functioning may be negatively affected by vestibular disorders early on in the disease process.

In contrast to earlier studies ${ }^{34,39}$ which included only asymptomatic, early stage participants, the most extensive study thus far has been by Teggi et al. ${ }^{18}$ These authors assessed $60 \mathrm{HIV}$-positive adults with vestibular symptoms, who reported a history of balance disorders and chronic dizziness. Participants' disease stage ranged across three Centers for Disease Control categories. Their reported prevalence of vestibular involvement is presented in Table II. Unsurprisingly, the prevalence of central vestibular involvement increased from 3.3 per cent in the early stages of the disease to 100 per cent in the advanced stages. Peripheral vestibular disorders occurred in one-third of patients in the early stages of the disease, rising to one-half of patients in the advanced stages.

The only report ${ }^{29}$ on vestibular manifestations associated with HIV / AIDS in the paediatric population indicated a high prevalence of abnormal auditory and vestibular function. However, the exact prevalence

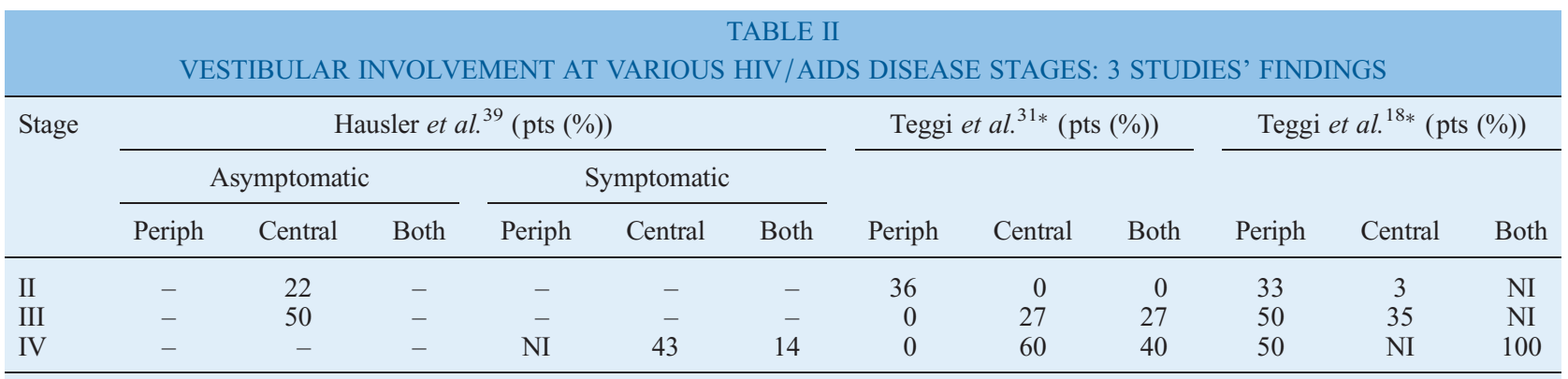

${ }^{*}$ All symptomatic. HIV = human immunodeficiency virus; AIDS = acquired immunodeficiency syndrome; pts = patients; periph = peripheral; $\mathrm{NI}=$ test results not indicated in study 
and nature of vestibular involvement (whether peripheral or central) was not indicated.

\section{Aetiology of acquired immunodeficiency syndrome related vestibular involvement}

Vestibular involvement occurs in HIV-positive children and adults irrespective of disease stage. The exact pathological mechanisms are still unclear. However, the four case report studies and three postmortem studies (one of which was also a case report) identified by the present review provide some information on possible contributing factors. Dizziness, vertigo, disequilibrium or imbalance may result when there is a lesion or dysfunction in the vestibular, visual and/or proprioceptive system. ${ }^{20}$ Human immunodeficiency virus associated dysfunction in any of these systems may potentially result in balance disturbance, especially if affecting the vestibular and neurological systems. $^{23}$ Opportunistic infections and ototoxic medications associated with HIV/AIDS may also cause (or contribute to) vestibular symptoms. In the present review, the four identified case report studies of HIV-infected adults complaining of dizziness and imbalance demonstrate the causal role of opportunistic infections.

\section{Case report studies}

Macher's study ${ }^{30}$ reported a number of HIV-positive adults with conditions such as syphilitic meningitis, secondary syphilis, a syphilitic mass in the internal auditory canal, and oto- and neurosyphilis, in whom symptoms indicated vestibular involvement. Only two of these cases received a partial vestibular examination. In one case (with secondary syphilis), caloric test results indicated bilateral vestibular function loss, resulting in dizziness and persistent imbalance. In the other case, vestibular examination utilised the Romberg test; a positive result confirmed the presence of a syphilitic mass in the left internal auditory canal.

Song et $a l .{ }^{33}$ reported the case of an adult diagnosed with otosyphilis who presented with auditory and vestibular symptoms, including sensorineural hearing loss, dizziness and imbalance. Caloric testing revealed progressive involvement of the peripheral vestibular system. Initial caloric test results indicated unilateral vestibular dysfunction; two months later, total bilateral vestibular dysfunction was evident. The authors concluded that the incidence of syphilis is increasing in patients with HIV/AIDS, and that otosyphilis (diagnosed from auditory and vestibular symptoms and serological testing) is a commonly associated disease with severe sequelae.

Grimaldi et al. $^{37}$ described bilateral cochleovestibular nerve neuropathy in an HIV-positive adult with sudden bilateral hearing impairment, high fever and vomiting. There were no reported vestibular symptoms such as vertigo, dizziness or imbalance. However, brainstem auditory evoked potentials and bithermal caloric testing suggested bilateral involvement of both the cochlear and vestibular nerves. Vestibular nerve involvement was diagnosed solely on the results of the caloric test, as no other vestibular assessment procedures were performed. The authors called for research into VIIIth cranial nerve neuropathy associated with HIV/AIDS, since the pathogenesis is still unknown.

Hart et $a l^{40}$ reported an adult AIDS patient with complaints of vestibular symptoms such as dizziness, lightheadedness and imbalance, as well as cognitive changes. Vestibular examination revealed abnormal results for pursuit tracking and optokinetic testing. Caloric testing also revealed central vestibular involvement, suggesting a brainstem lesion. The patient was subsequently diagnosed with subacute encephalitis (commonly associated with HIV/AIDS), which was the probable cause of vestibular changes. The authors suggested that auditory and vestibular assessment tests could be useful tools with which to monitor the progression of subacute encephalitis (characterised by subtle cognitive changes even in the early stages of the disease).

\section{Post-mortem studies}

Two group studies were conducted postmortem. ${ }^{36,38} \mathrm{~A}$ third study comprised a case presentation, with auditory and vestibular test results, together with subsequent post-mortem findings. ${ }^{40}$ Post-mortem studies of microstructural changes may help elucidate the possible mechanisms of HIV-related vestibular involvement. $^{36,38}$

Pappas and colleagues' findings ${ }^{36}$ indicated not only that the CNS is vulnerable to direct viral infection, but that their patients' peripheral vestibular labyrinth neuroepithelium contained viral-like particles characteristic of HIV. Specifically, pathology was observed within the cristae ampullares as well as in both otolith organs (i.e. the utricle and saccule). Chandrasekhar et al. ${ }^{38}$ reported similar abnormalities within the utricle and saccule, together with precipitations in the fluid-filled semicircular canals. This suggests that HIV affects the peripheral vestibular system directly, and could explain the presence of peripheral vestibular dysfunction and the symptoms of chronic imbalance and dizziness reported by participants of a recent study. ${ }^{18}$ The semicircular canals and otolith organs are the receptor organs for balance; their function is primarily to maintain postural stability and to aid spatial orientation, as well as keeping the eyes focussed on a target of interest while the head is moving. $^{23}$

Hart and colleagues' case presentation, ${ }^{40}$ of a deceased HIV-positive adult with vertigo attacks and imbalance, also reported autopsy findings which indicated neuronal loss in the area of the vestibular-cerebellar projections, with inflamed cells in the vestibular nuclei. The vestibular assessment performed premortem suggested central vestibular involvement, and the subsequent autopsy confirmed these findings. 


\section{Conclusion}

Individuals living with HIV / AIDS now have improved life expectancy due to improvements in treatment.

However, their overall quality of life may be limited by persistent vestibular symptoms such as vertigo, dizziness and/or imbalance. Peripheral and central vestibular functioning may be affected, irrespective of age or disease stage. However, the prevalence of central vestibular disorders seems to be greater, compared with peripheral disorders, especially at more advanced stages of the disease.

The aetiology of HIV/AIDS-associated vestibular dysfunction is complex, and may include direct effects of the virus on the peripheral and central vestibular system, together with the effects of a variety of HIV/AIDS-associated opportunistic infections (e.g. otosyphilis, encephalitis and cochleovestibular nerve neuropathy).

\section{References}

1 Nwaorgu O, Kokong D, Onakoya P, Adoga S, Ibekwe T. Prevalence of human immunodeficiency virus seropositivity in head and neck malignancies in sub-Saharan Africa. Acta Otolaryngol 2007;127:1218-21

2 Marcusen DC, Sooy CD. Otolaryngologic and head and neck manifestations of acquired immunodeficiency syndrome (AIDS). Laryngoscope 1985;95:401-5

3 Singh B. Alterations in head and neck cancer occurring in HIVinfected patients: results of a pilot, longitudinal, prospective study. Acta Oncol 1999;38:1047-50

4 Barzan L, Tavio M, Tirelli U, Comoretto R. Head and neck manifestations during HIV infection. J Laryngol Otol 1993;107:133-6

5 Neurotologic manifestations of HIV infection. In: http://www. bcm.edu/oto/grand/32494.html [21 January 2010]

6 Somefun A, Nwawolo CC, Okeowo PA, Ogban LU, Akanmu AS, Okanny CC et al. Otorhinolaryngological manifestations of HIV/AIDS in Lagos. Niger Postgrad Med J 2001;8: $170-4$

7 Lubbe DE. HIV and ENT. Continuing Medical Education 2004; 22:250-3

8 Rey D, L'Heritier A, Lang JM. Severe ototoxicity in a health care worker who received post-exposure prophylaxis with stavudine, lamivudine, and nevirapine after occupational exposure to HIV. Clin Infect Dis 2002;34:417-22

9 Rinaldo A, Brandwein MS, Devaney KO, Ferlito A. AIDSrelated otological lesions. Acta Otolaryngol 2003;123:672-4

10 Beers SL, Abramo TJ. Otitis externa review. Pediatr Emerg Care 2004;20:250-6

11 Gurney TA, Murr A. Otolaryngology manifestations of human immunodeficiency virus infection. Otolaryngol Clin North Am 2003;36:607-24

12 Stearn N, Swanepoel DW. Sensory and neural auditory disorders associated with HIV/AIDS. In: Swanepoel DW, Louw $\mathrm{B}$, eds. HIV/AIDS Related Communication, Hearing and Swallowing Disorders. San Diego, Oxford, Brisbane: Plural Publishing, 2010;243-88

13 Newton PJ. The causes of hearing loss in HIV infection. Community Ear and Hearing Health 2006;3:11-14

14 Jastreboff PJ, Hazell JWP. Tinnitus Retraining Therapy: Implementing the Neurophysiological Model. Cambridge: Cambridge University Press, 2004

15 Bankaitis AE, Keith RW. Audiological changes associated with HIV infection. Ear Nose Throat J 1995;74:353-8

16 Reyes-Contreras L, Silva-Rojas A, Ysunza-Rivera A, JimenezRuiz G, Berruecos-Villalobos P, Romo-Gutierrez G. Brainstem auditory evoked response in HIV-infected patients with and without AIDS. Arch Med Res 2002;33:25-8

17 Zuniga J. Communication disorders and HIV disease. J Int Assoc Physicians AIDS Care 1999;5:16-23
18 Teggi R, Ceserani N, Luce FL, Lazzarin A, Bussi M. Otoneurological findings in human immunodeficiency virus positive patients. J Laryngol Otol 2008;122:1289-94

19 Kevetter GA, Correia MJ. Vestibular system. In: Roland PS, Marple BF, Meyerhoff WL, eds. Hearing Loss. New York: Thieme, 1997;54-70

20 Bennet M. The vertigo case history. In: Jacobson GP, Shepard NT, eds. Balance Function Assessment and Management. San Diego, Oxford, Brisbane: Plural Publishing, 2008;45-62

21 Khoza K, Ross E. Auditory function in a group of adults infected with HIV/AIDS in Gauteng, South Africa. $S$ Afr $J$ Commun Disord 2002;49:17-27

22 Marra CM, Wechkin HA, Longstreth WT, Rees TS, Syapin CL, Gates GA. Antiretroviral therapy in patients infected with HIV1. Arch Neurol 1997;5:407-10

23 Hofmeyr L, Baker M. Balance disorders associated with HIV/ AIDS. In: Swanepoel DW, Louw B, eds. HIV/AIDS Related Communication, Hearing and Swallowing Disorders. San Diego, Oxford, Brisbane: Plural Publishing, 2010;289-349

24 Zapor MJ, Cozza KL, Wynn GH, Wortmann GW, Scott CA. Antiretrovirals, part II: focus on non-protease inhibitor antiretrovirals (NRTIs, NNRTIs, and fusion inhibitors). Psychosomatics 2004;45:524-35

25 Mira E. Improving the quality of life in patients with vestibular disorders: consequences of vestibular disorders. Int J Clin Pract 2008;62:109-14

26 Fielder H, Denholm SW, Lyons RA, Fielder CP. Measurements of health status in patients with vertigo. Clin Otolaryngol 1996; 21:124-6

27 Da Silva JG, Hyppolito MA, De Oliveira JA, Corrado AP, Ito IY, Carvalho I. Aminoglycoside antibiotic derivatives: preparation and evaluation of toxicity on cochlea and vestibular tissues and antimicrobial activity. Bioorg Med Chem 2007;15: 3624-34

28 Selimoglu E. Aminoglycoside-induced ototoxicity. Curr Pharm Des 2007;13:119-26

29 Palacios GC, Montalvo MS, Fraire MI, Leon E, Alvarez MT, Solorzano F. Audiologic and vestibular findings in a sample of human immunodeficiency virus type-1-infected Mexican children under highly active antiretroviral therapy. Int $J$ Pediatr Otorhinolaryngol 2008;72:1671-81

30 Macher AM. Otosyphilis: auditory and vestibular presentations. American Jails 2008;22:61-5

31 Teggi R, Giordano L, Pistorio V, Bussi M. Vestibular function in HIV patients: preliminary report. Acta Otorhinolaryngol Ital 2006;26:140-6

32 Dellepiane M, Medicina MC, Mora R, Salami A. Static and dynamic posturography in patients with asymptomatic HIV-1 infection and AIDS. Acta Otorhinolaryngol Ital 2005;25:353-8

33 Song JJ, Lee HM, Chae SW, Hwang SJ. Bilateral otosyphilis in a patient with HIV infection. Eur Arch Otorhinolaryngol 2005; 262:972-4

34 Castello E, Baroni N, Pallestrini E. Neurotological and auditory brain stem response findings in human immunodeficiency viruspositive patients without neurologic manifestations. Ann Otol Rhinol Laryngol 1998;107:1054-60

35 Johnston JL, Miller JD, Nath A. Ocular motor dysfunction in HIV-1-infected subjects: a quantitative oculographic analysis. Neurology 1996;46:451-7

36 Pappas DG Jr, Roland JT Jr, Lim J, Lai A, Hillman DE. Ultrastructural findings in the vestibular end-organs of AIDS cases. Am J Otol 1995;16:140-5

37 Grimaldi LME, Luzi L, Martino GV, Furlan R, Nemni R, Antonelli A et al. Bilateral eighth cranial nerve neuropathy in human immunodeficiency virus infection. J Neurol 1993;240: 363-6

38 Chandrasekhar SS, Siverls V, Chandra Sekhar HK. Histopathologic and ultrastructural changes in the temporal bones of HIV-infected human adults. Am J Otol 1992;13: 207-14

39 Hausler R, Vibert D, Koralnik IJ, Hirschel B. Neuro-otological manifestations in different stages of HIV infection. Acta Otolaryngol Suppl 1991;481:515-21

40 Hart CW, Cokely CG, Schupbach J, Dal Canto MC, Coppleson LW. Neurotologic findings of a patient with acquired immune deficiency syndrome. Ear Hear 1989;10:68-76

41 Kohan D, Hammerschlag PE, Holliday RA. Otologic diseases in AIDS patients: CT correlation. Laryngoscope 1990;11:1326-30 
42 Van der Stappen A, Wuytts FL, Van de Heyning PH. Computerized electronystagmography: normative data revisited. Acta Otolaryngol 2000;120:724-30

43 Halmagyi GM, Cremer PD, Anderson J, Murofushi T, Curthoys S. Isolated directional preponderance of caloric nystagmus: I. Clinical significance. Am J Otol 2000;21:559-67

Address for correspondence:

Dr Barbara Heinze,

Department of Communication Pathology,
Private Bag X20,

Hatfield,

Pretoria,

0028, South Africa

Fax: +27 124203517

E-mail: barbara.heinze@up.ac.za

Dr B Heinze takes responsibility for the integrity of the content of the paper

Competing interests: None declared 
APPENDIX I

\begin{tabular}{|c|c|c|c|c|c|c|c|c|c|c|}
\hline \multicolumn{11}{|c|}{$\begin{array}{l}\text { APPENDIX I } \\
\text { IN HIV/AIDS }\end{array}$} \\
\hline \multicolumn{3}{|c|}{ Study } & \multicolumn{4}{|c|}{ Patients } & \multicolumn{2}{|c|}{ Controls } & \multirow[t]{2}{*}{ Tests } & \multirow[t]{2}{*}{ Findings } \\
\hline Authors & Year & Design & $n$ & Symptom & ARV? & HIV staging & n & Symptom & & \\
\hline Teggi et al. ${ }^{18}$ & 2008 & Group study & $60 \mathrm{HIV}+$ adults & $\begin{array}{l}\text { Yes: chronic } \\
\text { dizziness } \\
\text { was inclusion } \\
\text { criteria }\end{array}$ & NI & $\mathrm{CDC}$ & 30 HIV- adults & $\begin{array}{l}\text { Yes: chronic } \\
\text { dizziness was } \\
\text { inclusion } \\
\text { criteria }\end{array}$ & $\begin{array}{l}\text { Audiometry, } \\
\text { spontaneous } \\
\text { nystagmus, } \\
\text { positional \& } \\
\text { positioning tests, } \\
\text { caloric tests }\end{array}$ & $\begin{array}{l}\text { Progressive } \\
\text { vestibular damage } \\
\text { through stages. } \\
\text { Higher incidence } \\
\text { of central } \\
\text { vestibular damage } \\
\text { at advanced stages }\end{array}$ \\
\hline Palacios et al. ${ }^{29}$ & 2008 & Group study & $\begin{array}{l}23 \mathrm{HIV}+ \\
\text { children }\end{array}$ & NI & Yes & $\mathrm{CDC}$ & No & NA & $\begin{array}{l}\text { Audiometry, ABR, } \\
\text { ENG (specific } \\
\text { tests NI), smooth } \\
\text { pursuit, caloric } \\
\text { tests, rotatory tests }\end{array}$ & $\begin{array}{l}\text { HIV may directly } \\
\text { affect both } \\
\text { peripheral \& } \\
\text { central vestibular } \\
\text { systems, although } \\
\text { opportunistic } \\
\text { infections \& drugs } \\
\text { can also be } \\
\text { responsible }\end{array}$ \\
\hline Macher $^{30}$ & 2008 & Case study & $6 \mathrm{HIV}+$ adults & $\begin{array}{l}\text { Yes: all cases had } \\
\text { dizziness or } \\
\text { imbalance }\end{array}$ & NI & NI & No & NA & $\begin{array}{l}\text { Romberg test in one } \\
\text { case, informal } \\
\text { nystagmus } \\
\text { observation in } \\
\text { another }\end{array}$ & $\begin{array}{l}\text { CN VIII \& peripheral } \\
\text { vestibular system } \\
\text { involvement in } \\
\text { syphilitic } \\
\text { meningitis }\end{array}$ \\
\hline Teggi et al. ${ }^{31}$ & 2006 & Group study & $30 \mathrm{HIV}+$ adults & $\begin{array}{l}\text { Yes: history of } \\
\text { balance } \\
\text { disorders }\end{array}$ & NI & $\mathrm{CDC}$ & No & NA & $\begin{array}{l}\text { Dynamic Gait Index, } \\
\text { smooth pursuit, } \\
\text { saccade, } \\
\text { positional tests, } \\
\text { caloric tests }\end{array}$ & $\begin{array}{l}\text { Peripheral \& central } \\
\text { vestibular damage } \\
\text { may occur at any } \\
\text { stage, although } \\
\text { higher incidence } \\
\text { of central } \\
\text { vestibular damage } \\
\text { at advanced stages }\end{array}$ \\
\hline $\begin{array}{l}\text { Dellepiane } \\
\text { et al. }{ }^{32}\end{array}$ & 2005 & Group study & $\begin{array}{l}15 \text { HIV + adults } \\
15 \text { AIDS } \\
\text { adults* }\end{array}$ & No & NI & $\mathrm{CDC}$ & $55 \mathrm{HIV}-$ adults & No & $\begin{array}{l}\text { Static \& dynamic } \\
\text { posturography }\end{array}$ & $\begin{array}{l}\text { Involvement of entire } \\
\text { vestibular system, } \\
\text { even in early } \\
\text { stages \& } \\
\text { asymntomatic pts }\end{array}$ \\
\hline Song $\mathrm{et} \mathrm{al}^{33}$ & 2005 & Case study & $1 \mathrm{HIV}+$ adult & $\begin{array}{l}\text { Yes: dizziness \& } \\
\text { progressive HL }\end{array}$ & NI & NI & No & NA & $\begin{array}{l}\text { Audiometry, caloric } \\
\text { tests }\end{array}$ & $\begin{array}{l}\text { Otosyphilis is } \\
\text { frequently } \\
\text { associated with } \\
\text { auditory \& } \\
\text { vestibular } \\
\text { symptoms }\end{array}$ \\
\hline Castello et al. ${ }^{34}$ & 1998 & Group study & 29 HIV + adults & No & NI & $\mathrm{CDC}$ & 20 HIV-adults & No & $\begin{array}{l}\text { ABR, spontaneous \& } \\
\text { positional } \\
\text { nystagmus, } \\
\text { pursuit, saccades, } \\
\text { caloric tests }\end{array}$ & $\begin{array}{l}\text { HIV infects CNS } \\
\text { even at early } \\
\text { stages. ABR \& } \\
\text { caloric tests } \\
\text { indicate no effect } \\
\text { of HIV on } \\
\text { labyrinth or CN } \\
\text { VIII }\end{array}$ \\
\hline
\end{tabular}




\begin{tabular}{|c|c|c|c|c|c|c|c|c|c|c|}
\hline \multicolumn{11}{|c|}{ APPENDIX I CONTINUED } \\
\hline \multicolumn{3}{|c|}{ Study } & \multicolumn{4}{|c|}{ Patients } & \multicolumn{2}{|c|}{ Controls } & \multirow[t]{2}{*}{ Tests } & \multirow[t]{2}{*}{ Findings } \\
\hline Authors & Year & Design & n & Symptom & ARV? & HIV staging & $n$ & Symptom & & \\
\hline Johnston et al. ${ }^{35}$ & 1996 & Group study & 13 HIV+ adults & No & NI & NI & 9 HIV-adults & No & $\begin{array}{l}\text { Oculomotor tests } \\
\text { (saccades \& } \\
\text { pursuit) }\end{array}$ & $\begin{array}{l}\text { Oculomotor tests } \\
\text { useful in } \\
\text { identifying CNS } \\
\text { dysfunction in } \\
\text { HIV+ adults }\end{array}$ \\
\hline Pappas et al. ${ }^{36}$ & 1995 & PM study & $12 \mathrm{HIV}+\mathrm{pts}^{\dagger}$ & NA & NA & NA & NA & NA & $\begin{array}{l}\text { Electron microscopic } \\
\text { ultrastructural } \\
\text { analysis of } \\
\text { vestibular end- } \\
\text { organs }\end{array}$ & $\begin{array}{l}\text { Pathology of } \\
\text { vestibular hair } \\
\text { cells, ampullae, } \\
\text { otolith organs, } \\
\text { labyrinth wall \& } \\
\text { epithelial lining }\end{array}$ \\
\hline Grimaldi et . $^{37}$ & 1993 & Case study & 1 HIV+ adult & $\begin{array}{l}\text { Yes: sudden, bilat } \\
\text { HL, } \\
\text { fever \& weight } \\
\text { loss }\end{array}$ & NI & NI & No & NA & $\begin{array}{l}\text { PTA, ABR, caloric } \\
\text { tests }\end{array}$ & $\begin{array}{l}\text { Bilateral involvement } \\
\text { of both branches } \\
\text { of vestibulo- } \\
\text { cochlear nerve }\end{array}$ \\
\hline 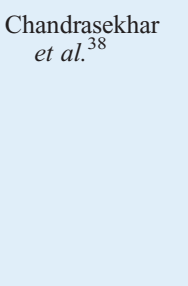 & 1992 & PM study & $10 \mathrm{HIV}+\mathrm{pts}^{\dagger}$ & NA & NA & NA & NA & NA & Electron microscopy & $\begin{array}{l}\text { Precipitations in peri- } \\
\text { and endolymph of } \\
\text { vestibule \& } \\
\text { semicircular } \\
\text { canals; } \\
\text { subepithelial } \\
\text { elevation of } \\
\text { neurosensory } \\
\text { epithelium of } \\
\text { otolith organs }\end{array}$ \\
\hline Hausler et al. ${ }^{39}$ & 1991 & Group study & 43 HIV+ adults & $\begin{array}{l}14 \text { stage IV pts were } \\
\text { symptomatic }\end{array}$ & NI & $\mathrm{CDC}$ & 33 HIV-adults & No & $\begin{array}{l}\text { PTA, stapedial } \\
\text { reflexes, ABR, } \\
\text { spontaneous \& } \\
\text { positional } \\
\text { nystagmus, } \\
\text { pursuit \& rotatory } \\
\text { tests, pendular \& } \\
\text { caloric tests }\end{array}$ & $\begin{array}{l}\text { Asymptomatic } \\
\text { HIV+ adults may } \\
\text { present with } \\
\text { auditory \& } \\
\text { vestibular } \\
\text { findings. At } \\
\text { advanced stages } \\
\text { both central \& } \\
\text { peripheral } \\
\text { vestibular } \\
\text { disorders occur }\end{array}$ \\
\hline Hart et al. ${ }^{40}$ & 1989 & $\begin{array}{l}\text { Case study \& } \\
\text { PM study }\end{array}$ & $1 \mathrm{HIV}+$ adult & $\begin{array}{l}\text { Yes: dizziness \& } \\
\text { disequilibrium }\end{array}$ & NI & NI & No & No & $\begin{array}{l}\text { PTA, speech } \\
\text { audiometry, ABR, } \\
\text { saccade \& pursuit } \\
\text { tests, caloric test }\end{array}$ & $\begin{array}{l}\text { Abnormal auditory \& } \\
\text { central vestibular } \\
\text { findings }\end{array}$ \\
\hline
\end{tabular}

cated; $\mathrm{CDC}=\mathrm{Centers}$ for Disease Control; $\mathrm{NA}=$ not applicable; $\mathrm{ABR}$
nervous system; $\mathrm{PM}=$ post-mortem; $\mathrm{PTA}=$ pure tone audiometry 